\title{
Geoffroy Heimlich (Ed.): Art Rupestre et Patrimoine Mondial en Afrique Subsaharienne
}

\author{
Maisonneuve \& Larose, Hémisphères Éditions, Paris, 2021, 244 pp., ISBN 978- \\ 2-3770-069-1
}

\author{
Emmanuelle Honoré
}

Accepted: 1 June 2021 / Published online: 17 June 2021

(C) The Author(s), under exclusive licence to Springer Science+Business Media, LLC, part of Springer Nature 2021

The edited book Art rupestre et patrimoine mondial en Afrique subsaharienne is one of the rare positive outcomes of the COVID-19 pandemic-this collection of papers takes the place of an international seminar that was to happen at the Institut National du Patrimoine in Paris in March 2020. The editor Geoffroy Heimlich describes the volume as "a kind of preliminary inventory" (p. 15) exposing the many challenges, research issues, and conservation, protection, and sustainable management initiatives for subSaharan rock art sites that are on the UNESCO World Heritage (hereafter WH) List and Indicative List.

The book is divided into three sections. It opens with a description of potentials and challenges (first section), while the major portion is about rock art sites on the WH List (second section) and on the Indicative List (third section).

Rock art sites in Africa are currently under-represented on the WH List. Only seven sites on the WH List have the presence of rock art as an essential element, though five of these are in sub-Saharan Africa. Four other sites in Africa on the WH List have rock art as a contributing element. Reasons for this include the great disparity in publications and a general lack of site inventories. A rare example of high-quality inventories in the field of African rock

E. Honoré $(\bowtie)$

Centre d'Anthropologie Culturelle, Université Libre de

Bruxelles, Brussels, Belgium

e-mail: emmanuelle.honore@ulb.be art are the series of publications by Harald Pager for the Drakensberg (Lesotho, South Africa) and the Brandberg (Namibia). An excursus on Saharan rock art is the starting point for J.-L. Le Quellec (Chapter 1) to suggest more efforts in making maps and to plea for reviving areological studies. In Chapter 2, Gwenaëlle Bourdin (Director of the evaluation unit at ICOMOS) reminds us that the quality of the supporting documentation is paramount. Several criteria can be used to evaluate a site for the WH List: (i) the chef-d'oeuvre; (ii) the evidence for exchanges; (iii) the exceptional testimony of a cultural tradition; (v) the traditional use of the territory, and (vi) the exceptional universal value.

Having a site on the WH List is not, however, a guarantee for a successful management. At the frontier between South Africa and Lesotho, the MalotiDrakensberg Park was added to the WH List in two steps in 2000 and 2013, after Lesotho finally ratified the UNESCO Convention in 2003. In Chapter 3, Mélanie Duval argues counter to the usual complacency and highlights the unbalanced management of funds (natural resources having been the subject of all efforts), the limited attention paid to rock art sites (especially in the Sotho side of the park), the hasty classification of the Sehlabathebe Park in spite of adverse recommendations, and the limited effects of the classification on the preservation of rock art sites. The trans-frontier configuration and the mixed nature (natural and cultural) of the site adds more challenges. 
In Zimbabwe, the MATOBART project was initiated in 2017 to study the Matobo Hills, previously inscribed as a "cultural landscape" in the WH List. The scientific work done by this FrenchZimbabwean mission under the direction of Camille Bourdier (Chapter 4) aims to develop a chrono-stylistic sequence and to contribute to the preservation of and communication about this heritage. Zimbabwean authorities are quite involved in these efforts despite a number of difficulties for heritage management in this country. In Chapter 5, Daouda Keita (General Director of the National Museum of Mali) and Seydou Ouattara (former director of the Bandiagara museum) warn how the political crisis of 2012 has threatened the WH Listed site of Songo, one of the most important Dogon rock art sites in Mali. Rock art is still refreshed on this 37-m-long panel every three years at the occasion of traditional male circumcision. The occupation of the region by jihadists in 2012 has put a brutal stop to such traditions, as well as research collaborations and tourism, and has even led to the ransacking of $\mathrm{WH}$ Listed sites. Intercommunity tensions could now follow in the destabilization of the Pays Dogon.

Frédérique Duquesnoy (Chapter 6) provides more lessons from the Tasīli-n-Ăjjer, the first ensemble of African sites inscribed in the WH List in 1982. Almost 40 years later, the inventory of rock art sites is still a simple list with no photographic library and no unique database. In Chapter 7, Yves Sanou argues that complete inventories are sometimes hard to establish due to the constant discovery of new rock art sites, as is the case in Burkina Faso. Yet, constant additions should not deter the establishment of centralized and normalized inventories. Three ensembles of sites in Burkina Faso are on the WH List, and four more are on the Indicative List, including the rock engravings of Arbinda, Pobe Mengao, and Markoye. Further field investigations and research publications are preconditions for electing WH sites. Yet, the security issues in this region are currently an impediment to the development of such initiatives. The petroglyph site of Bidzar in Cameroon faces the same situation. Narcisse Tchandeu and colleagues (Chapter 8) emphasize the need to complete the old documentation done by Alain Marliac in the 1980s and to establish protective measures to prevent new engravings from obliterating the site. However, they pass over the fact that Bidzar is located in northern Cameroon where several kidnappings have taken place in the recent years, making security issues a true obstacle to fieldwork-especially for international teams.

International collaborations can be a decisive stepping stone for preparing the inscription of a site on the WH List. Drawing on the work of Pierre de Maret, the French-Congolese mission led by Geoffroy Heimlich and Clément Mambu Nsangathi (Chapter 9) focuses on rock art in the vast region of the Lovo massif $\left(430 \mathrm{~km}^{2}\right)$. Since 2007 , the mission has made an inventory with detailed descriptions for 73 sites (about 70 were previously recorded) in addition to providing dates for some of these sites. Several African states have already made clear efforts to develop public policies for preserving and promoting cultural sites at the national level. In Angola, the Constitution recognizes culture as a core component for a united, developed, and prosperous nation. Several laws regulate the management of heritage, even though Ziva Domingos (Chapter 10) notes that financial efforts are not very substantial. Among the Angolan sites on the Indicative WH List, Tchitundu-Hulu has been the subject of a sustainable management and local development plan in preparation for the UNESCO application.

Much work remains to be done both from a research angle and a site management perspective. Approximately one-fourth of the rock art sites on the Indicative WH List are in Africa, and most of them still await research programs. At the same time, the documentation phase must come together with the management of sites-whether to promote strategies of preservation or communication initiatives. The contributors to this book unanimously stress the importance of involving local communities in all aspects or research and management. They must not be only "keepers" of sites.

Regarding format, the book's small size $(16 \mathrm{~cm}$ $\times 23 \mathrm{~cm}$ ), its thickness $(2 \mathrm{~cm})$, and the small central margins make it difficult to manipulate and read. Figures are grouped in color plates on glossy paper. Several authors provide original illustrations of great quality and interest, but some are printed in a ridiculously small size. This is the case for the 3D model of the Pomongwe shelter (plate XV) made by Magnus 
Haaland for the Matobo rock art project in Zimbabwe (Chapter 4): the complete scanned model of this shelter $(14 \mathrm{~m} \times 20 \mathrm{~m})$ is printed as a vignette barely larger than a postage stamp $(4 \mathrm{~cm} \times 7 \mathrm{~cm})$ with blank space all around. The plea for more efforts to document African rock art sites can begin with more attention to the quality of plates. However, this book will hopefully stimulate a new generation of collaborative projects on sites that are- or will be-on the UNESCO Indicative WH List.

Publisher's Note Springer Nature remains neutral with regard to jurisdictional claims in published maps and institutional affiliations. 